\title{
In-Silico Analysis of Procyanidin Type-A Extracted From Cinnamon for Diabetes Mellitus Type 2 Treatment
}

\author{
Risma Nila Anandari ${ }^{1}$, Siti Khaizatul Minnah ${ }^{1}$, Vidya Utami Widadni ${ }^{1}$, Dona Safira ${ }^{1}$, Fatchiyah \\ Fatchiyah $^{1}$ \\ ${ }^{1}$ Department of Biology, Faculty of Mathematics and Natural Sciences, Brawijaya University, Jalan Veteran, Malang, East Java, \\ Indonesia, 65145
}

Submission: 01 June 2021; Revised: 11 July 2021; Accepted: 26 September 2021

*Corresponding author: Risma Nila Anandari; e-mail: risma_anandari@student.ub.ac.id; tel.: -

\begin{abstract}
Type 2 diabetes mellitus (T2DM) is the most common disease in developing countries. People with type-2 diabetes are at high risk of complications leading to disability and premature death. Procyanidin compounds in cinnamon have an insulin-like activity that can regulate normal blood sugar levels. This research aimed to investigate the interaction between $\alpha$-glucosidase and $\alpha$-amylase with procyanidin $A$ and their potential for diabetes treatment therapy. Data mining receptor was downloaded from RCSB PDB and ligands from PubChem. Drug likeness properties were evaluated using SwissADME, while toxicity analysis was assessed using metatox. Molecular docking between $\alpha$ glucosidase and $\alpha$-amylase with procyanidin A was performed using HEX 8.0.0 and was visualized by Discovery Studio. Procyanidin A showed interaction with $\alpha$-glucosidase by non-bonds interaction, including hydrogen, hydrostatic and hydrophobic bonds, while procyanidin $A$ and $\alpha$-amylase formed hydrogen and hydrophobic bonds. Procyanidin $A$ is an alternative treatment for T2DM with a variety of supportive chemical bonds. Procyanidin A has an excellent ability to inhibit activity $\alpha$-glucosidase and $\alpha$-amylase in the process of breaking down glucose in the intestines.
\end{abstract}

Keywords: $\alpha$-amylase, $\alpha$-glucosidase, Cinnamon, Procyanidin A, T2DM

\section{INTRODUCTION}

Diabetes Mellitus is one of the most contagious and fastest-growing public health problems worldwide. This disease has a complex condition to treat and high care treatment costs. The number of people with diabetes globally was expected to be double from the current case of 190 million to 325 million in the next 25 years [1]. The causes of diabetes mellitus are distinguished into 4 , type I diabetes, type II diabetes, gestational diabetes mellitus, and other types of diabetes mellitus. Diabetes mellitus type 1 was characterized by the damage of $\beta$ cells due to autoimmune reactions. Type 2 diabetes mellitus is caused by the body that cannot respond to insulin, while gestational diabetes mellitus is caused by glucose intolerance during pregnancy. Other types of diabetes mellitus can be caused by genetic abnormalities, pancreatic disorders, to the influence of certain drugs or chemicals [2].

Type 2 diabetes mellitus (T2DM) is the most common type of diabetes [3]. People with T2DM can lead to disability and premature death because of the high risk of complications, such as cardiovascular disease, peripheral vascular disease, nephropathy, changes in the retina, and blindness. Genetic susceptibility and environmental influence are essential factors in diabetes mellitus for both T1DM and T2DM [1].
Genetic factors cause insulin resistance and $\beta$ cell failure, while obesity, aging, and lack of physical activity exacerbate inherited metabolic disorders [3].

T2DM was characterized by a rise in blood sugar due to decreased insulin secretion by pancreatic $\beta$ cells and impaired insulin function. In other studies, it was known that the ability to regenerate pancreatic $\beta$ cells in mice hyperglycemia depends on the regulation of normal blood glucose levels. Procyanidin compounds in cinnamon have an insulin-like activity that can regulate normal blood sugar levels. Procyanidin is a bioactive compound with antigenotoxic and cardiovascular protection effects and restoring inflammation or oxidative nature. In addition, procyanidin also has antiproliferative effects [3].

$\alpha$-glucosidase inhibitor (AGI) is one of the antidiabetic agents that work by inhibiting $\alpha$ glucosidase activity. Reducing carbohydrate absorption from food by the intestine becomes a therapeutic approach to postprandial hyperglycemia [4]. $\alpha$-amylase plays an essential role in breaking oligosaccharides and disaccharides into monosaccharides. Inhibition of $\alpha$-amylase decreased glucose absorption rate and prevented an increase in postprandial glucose plasma levels [5]. 
Acarbose is a common diabetes inhibitor that suppresses $\alpha$-glucosidase and $\alpha$-amylase activities [6]. The presence of $\alpha$-glucosidase and $\alpha$-amylase enzymes that interact with procyanidin is estimated to cause glucose levels in the blood to drop. Therefore, the potential of cinnamon compounds can be seen as an alternative treatment for T2DM. It is necessary to research the activity of procyanidin in T2DM based on its interaction with $\alpha$-glucosidase and $\alpha$-amylase using in silico molecular docking method. This method can be known for the affinity ligand bond tests and possible interactions so the potential of procyanidin $\mathrm{A}$ as a therapy in $\mathrm{T} 2 \mathrm{DM}$ can be predicted.

\section{RESEARCH METHODS}

\section{Data Mining}

$\alpha$-glucosidase (PDB ID 2QV4) and $\alpha$ amylase (PDB ID 5NN8) receptor structures were taken from the database RCSB PDB (https://www.rcsb.org/). While the ligand structures of procyanidin A (CID: 5089889) and Acarbose (CID: 41774) were retrieved from PubChem. Protein structures were downloaded in .pdf format and ligands in .sdf format.

\section{Drug Likeness and Toxicity Analysis of Ligands}

Drug likeness from ligands was defined based on SwissADME physicochemical properties, which describes a molecular weight, LogP value, number of $\mathrm{H}$-bond donor and $\mathrm{H}$-bond acceptor, rotatable bond, and Total Polar Surface Area (TPSA) from ligands. The toxicity analysis from ligands was determined using metatox, including the prediction value of toxicity and integral toxicity.

\section{Molecular Docking}

Discovery Studio and PyRx were used to optimize protein and ligands. Then, the molecular docking process was performed using HEX 8.0.0 with Shape+Electro for correlation type.

\section{Analysis and Visualization}

The molecular docking results from protein and ligands were analyzed using Discovery Studio. In addition, the interaction site that formed was analyzed from ligand-residue interaction and visualized with a $2 \mathrm{D}$ diagram.

\section{RESULTS AND DISCUSSIONS}

Molecular docking was performed between procyanidin compounds with $\alpha$-glucosidase and $\alpha$ amylase to determine the interaction between ligands and proteins. Acarbose was used as a control both for $\alpha$-glucosidase and $\alpha$-amylase proteins. Procyanidin A depicted several interactions between $\alpha$-glucosidase and $\alpha$-amylase (Figure 1-2). $\alpha$-glucosidase and procyanidin A showed several hydrophobic interactions (Figure 1A). Procyanidin A forms hydrogen bonds with the amino acid Gly651 residue. A Pi-anion bond is created with the amino acid residues Asp612 and Asp282. The reaction of amino acids Ala284 and Leu678 A with procyanidin A forms a Pialkyl bond. The Pi-sigma bond formed through the Leu678 interaction. The interaction with Trp481 creates the Pi-Pi bond. Based on the molecular docking results, the energy obtained is $337.07 \mathrm{~kJ} / \mathrm{mol}$.

Acarbose performed several binding sites of $\alpha$-glucosidase. Most of these bonds are hydrogen. $\alpha$-glucosidase will form hydrogen bonds, namely conventional hydrogen-bonds and carbon hydrogen-bonds with amino acid residues Ala284, Asp282, Asp616. Meanwhile, the amino acid residue of Phe52 with $\alpha$-glucosidase will form a Pi-alkyl bond. The energy obtained was -351.65 $\mathrm{kJ} / \mathrm{mol}$ (Figure 1B).
A

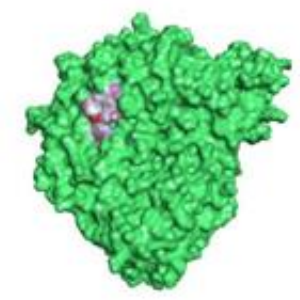

B

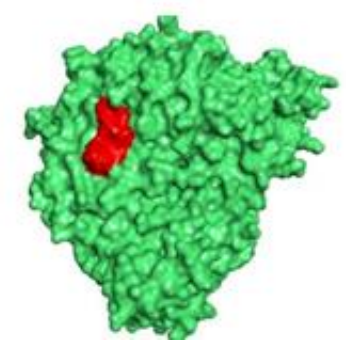

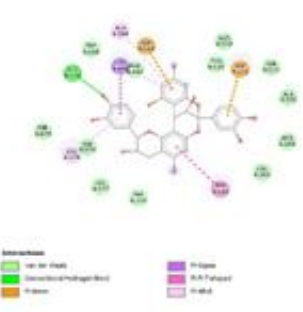

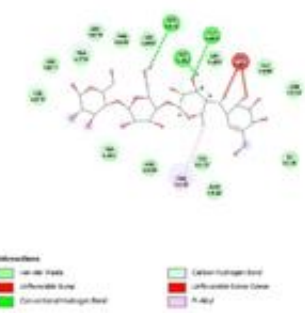

Figure 1. The binding model of procyanin $A$ and acarbose with $\alpha$-glucosidase protein. A. Procyanin A - $\alpha$-glucosidase interaction, B. acarbose - $\alpha$-glucosidase interaction. Procyanin A was illustrated in purple, acarbose in red, and $\alpha$-glucosidase protein was shown in green.

The binding to the amino acid residues Ala284, Asp282, and Asp616 is predicted that these amino acids bind the active site of the $\alpha$ glucosidase enzyme. According to Fakih \& Dewi, a molecular interaction formed between the $\alpha$ glucosidase enzyme and Acarbose, which consists of 14 hydrogen bonds with Asp232, Ala234, Asn237, Asp357, Arg552, Asp568, and His262. Then there were three hydrophobic interactions with Trp 329, Trp432, and Phe601 [7]. Alanin and Asparagin were identified as the active site of $\alpha$ - 
glucosidase enzyme. Asp242 was reported as catalytic residue of $\alpha$-glucosidase and might important inhibition site and regulated $\alpha$ glucosidase activities [8].

Procyanidin A performed unfavorable bump in Ala310, hydrogen bond at Gly351 and hydrophobic interactions at $\operatorname{Trp} 269$ of $\alpha$-amylase. The energy created from the interaction of the $\alpha$ amylase bond with procyanidin $\mathrm{A}$ is -321.26 $\mathrm{kJ} / \mathrm{mol}$ (Figure 2A). Acarbose also identified has several interactions with $\alpha$-amylase. There were GLU233 with unfavourable bump, ILE235 and HIS201 with hydrogend bond, also TYR151 with hydrophobic interaction. Acarbose - $\alpha$-amylase binding produced $-349.65 \mathrm{~kJ} / \mathrm{mol}$ of binding energy (Figure 2B). The energy value will affect the protein-ligand bond disruption, where the lower energy value indicated the more stable the protein-ligand interaction [9].

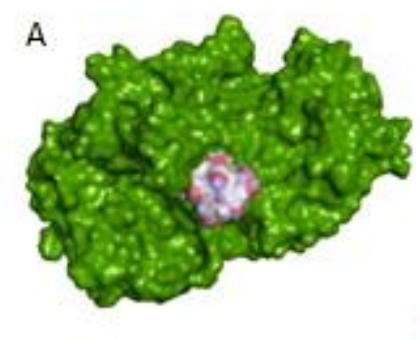

B

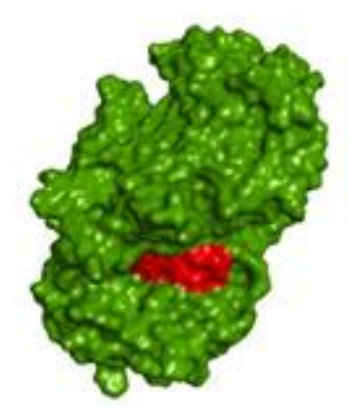

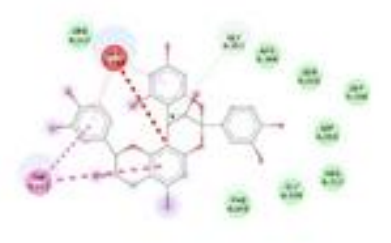
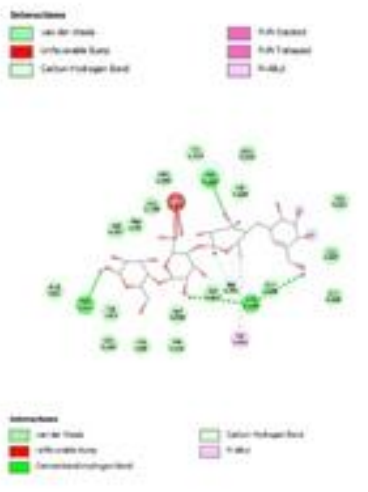

Figure 2. The binding model of procyanin $\mathrm{A}$ and acarbose with $\alpha$-amylase protein. A. Procyanin A - $\alpha$-glucosidase interaction, B. acarbose - $\alpha$-glucosidase interaction. Procyanin A was illustrated in purple, acarbose in red, and $\alpha$-amylase protein was shown in dark-green.

Drug likeness results in procyanidin compounds showed three ligand properties that did not meet Lipinski's rules. First, the molecular weight of more than $500 \mathrm{Da}$ is $576.50 \mathrm{~g} / \mathrm{mol}$, the number of donor bonds as much as 9, and the number of bond acceptors as much as 12 . Molecular weights over $500 \mathrm{Da}$ cannot diffuse through cell membranes. Third, the number of donors and acceptors of hydrogen bonds describes the higher the capacity of hydrogen bonds, the higher the energy needed for the absorption process to occur [8].

Toxicity predictions performed with Metatox showed LD50 results in procyanidin A and Acarbose. The predicted value on the structure of the procyanidin compound in toxicity oral has LD50 $7.548 \mathrm{mg} / \mathrm{kg}$, while in Acarbose is 3.435 $\mathrm{mg} / \mathrm{kg}$. The value of LD50 was classified as practically non-toxic, mild toxicity, moderate toxicity, highly toxic, very highly toxic, and super toxic. The lower the value of LD50 in a compound, the greater its toxic properties (Pratiwi et al., 2014). These results indicate that LD50 of Acarbose is lower than procyanidin A.

\section{CONCLUSION}

Procyanidin A has an excellent ability to inhibit activity $\alpha$-glucosidase and $\alpha$-amylase in the process of breaking down glucose in the intestines. Therefore procyanidin A which is derived from cinnamon, can be used as an alternative treatment for T2DM. For maximum results, natural compounds other than procyanidin A which also has the potential for T2DM therapy can be added.

\section{ACKNOWLEDGEMENT}

We send our regards to our bioinformatics lectures also lab assistants for helping us to finish this research. And thanks to our amazing classmates this semester for the discussion during this mini-project.

\section{REFERENCES}

[1] Asif, M. 2016. The prevention and control the type- 2 diabetes by changing lifestyle and dietary pattern. $J$ Edu Health Promot. 3(1) : 1-8.

[2] Emilda, E. 2018. Efek senyawa bioaktif kayu manis (Cinnamomum burmannii Nees ex.bl.) terhadap diabetes melitus : kajian pustaka. JFFI. 5(1):246-252.

[3] Abuin, N. G., Montserrat P., Angela C. M., Lluis A., Mayte B., Anna A. 2015. Procyanidins and Their Healthy Protective Effects Against Type 2 Diabetes. Current Medicinal Chemistry. $22: 39-50$.

[4] Susanti, N. M., Saputra D. P. D., Hendrayanti P. L., Parahyangan I. P. D. N., Swandari I. A. D. G. 2018. Molecular Docking Sianidin dan Peonidin Sebagai Antiinflamasi pada Aterosklerosis Secara In Silico. Jurnal Farmasi Udayana. 7(1) : 28- 33. 
[5] Wardhani, N. A. K., Andini., Putri T. I., Dinda I. S. 2017. Enzim $\alpha$-Amilase Inhibitor Pada Ekstrak Air Kacang Merah (Phaseolus vulgaris L.) Untuk Penanggulangan Diabetes Melitus. 1(2) : 50-59.

[6] Sari, I. W., Junaidin J., Dina P. 2020. Studi Molecular Docking Senyawa Flavonoid Herba Kumis Kucing (Orthosiphon stamineus B.) Pada Reseptor $\quad \alpha$-glucosidase Sebagai Antidiabetes Tipe 2. Jurnal Farmagazine. 7(2) : 54-60.

[7] Fakih, T. M., Dewi, M. L. 2020. Identifikasi peptida bioaktif dari protein kedelai sebagai inhibitor enim alfaglucosidase untuk kandidat antidiabetes. Jurnal Farmasi Indonesia. 17(2):1-9.

[8] Weni, M., Mega S., Djarot S. H. S. 2020. Molecular Docking of Active Compounds Piper crocatum on The Alpha-Glucosidase Enzyme Antidiabetic. IJPST. 7(2) : 64-72.

[9] Rachmania, R.A. 2019. Validasi protokol skrining virtual dan analisis interaksi inhibitor antiproliferasi sel kanker berbasis bahan alam terhadap reseptor cyclin-dependent kinase 4 (CDK4). Media Farmasi. 16(1):21- 40. 